\title{
4. 添付文書における相互作用に関する記載について
}

\author{
永 井 尚 美*
}

\section{1. はじめに}

医療現場では，異なる診療科を受診して複数の治療 薬が処方される場合, 同一疾病の治療においても作用 機序の異なる治療薬が処方される場合等, 処方薬間の 相互作用に注意を要する状況にしばしば遭遇する。ま た，薬物間の相互作用のみならず，飲食物，喫煙や嘹 好品等による薬物治療への影響にも考慮が必要な場合 がある．医療の現場で起こり得る相互作用を適切にマ ネジメントするためには，併用により引き起こされる 薬物の生体内挙動の変動を予測し, この薬物動態の変 動が有効性や安全性に及ぼす影響を正しく評価しなく てはならない.

新薬の開発では, 非臨床から臨床開発の各段階で薬 物相互作用に関する検討を実施してデータを得るが, 承認後には, 収集されたデータおよびデー夕に基づく 注意喚起の情報が, 添付文書等を通じて適切に医療現 場に提供されなくてはならない.

本稿では, 医療用医薬品の添付文書における相互作 用の記載とその根拠となる医薬品開発時の検討事項 （現在の指針における相互作用検討の基本原則と方法） を概説する．また，最新の技術・科学的水準や国際調 和を踏まえた薬物相互作用検討のために，本邦の指針 の改訂作業が進められているが，その改訂内容につい て，ならびに薬事法改正案における添付文書の位置付 けについて紹介する。

\section{2. 薬物相互作用の検討方法について(平成 13 年 6 月 4 日, 医薬審発第 813 号)}

薬物相互作用とは, 薬物の効果・副作用あるいは薬 物動態に影響を及ぼす併用薬物間および薬物と飲食 物，嗜好品等との間に起こる現象である.

医療現場で処方された複数の薬物を併用した結果,
死亡を含む重篤な副作用が生じたことにより，薬物相 互作用が社会的な問題となったテルフェナジンやソリ ブジン等の経験を踏まえ, 約 10 数年前に日米欧の各 極で薬物相互作用に関する行政指針が作成された。本 邦では 2001 年 6 月に「薬物相互作用の検討方法 」ا が 発出され，さらに解説書および英語版の「Methods of Drug Interaction Studies」も公表されている ${ }^{2)}$.「薬物 相互作用の検討方法」では, 医薬品開発時に薬物相互 作用を検討する際の基本原則とともに，薬物の生体内 挙動（吸収・分布・代謝・排泄：ADME）の全過程に ついて，薬物相互作用に関する検討項目と留意事項を 示している (Fig. 1). 医薬品開発における薬物相互作 用の検討は, 開発医薬品の薬物動態プロファイルを把 握し, 非臨床および臨床開発の各段階で計画的・系統 的に進める必要がある。 ヒト組織や発現系を用いた非 臨床 in vitro 試験の実施と臨床薬物動態情報より, ヒ トにおいて相互作用を生じ得る薬物動態上の機序を早 い段階から評価し, 開発医薬品と臨床現場で併用され る可能性のある既承認薬について，相互作用を受ける 可能性（被相互作用薬）と与える可能性（相互作用薬） の両面から系統的に評価する.

Fig. 2 では，経口投与開発薬が代謝阻害の相互作用 薬となる場合の薬物相互作用検討の概念図を示した. まず，ヒト由来試料を用いた非臨床の検討を実施し， 阻害の様式やパラメータに基づき臨床での相互作用試 験実施の必要性を判断する．臨床開発の早期の段階で は，主として健康被験者を対象に代表的な指標薬を用 いた臨床相互作用試験を実施して，臨床現場で起こる 可能性が高い相互作用について検討する．引き続き臨 床開発の後期において，適応患者に臨床用量が投与さ れる第 II 相および/または III相試験での併用薬の情報 に基づき，臨床で生じる可能性が示唆される相互作用

Key words: drug interaction, package inserts, drug development, Pharmaceutical Affairs Law, regulatory guidance/guideline

* 独立行政法人医薬品医療機器総合機構 † 100-0013 東京都千代田区霞が関 3-3-2 新霞が関ビル

E-mail : nagai-naomi@pmda.go.jp 


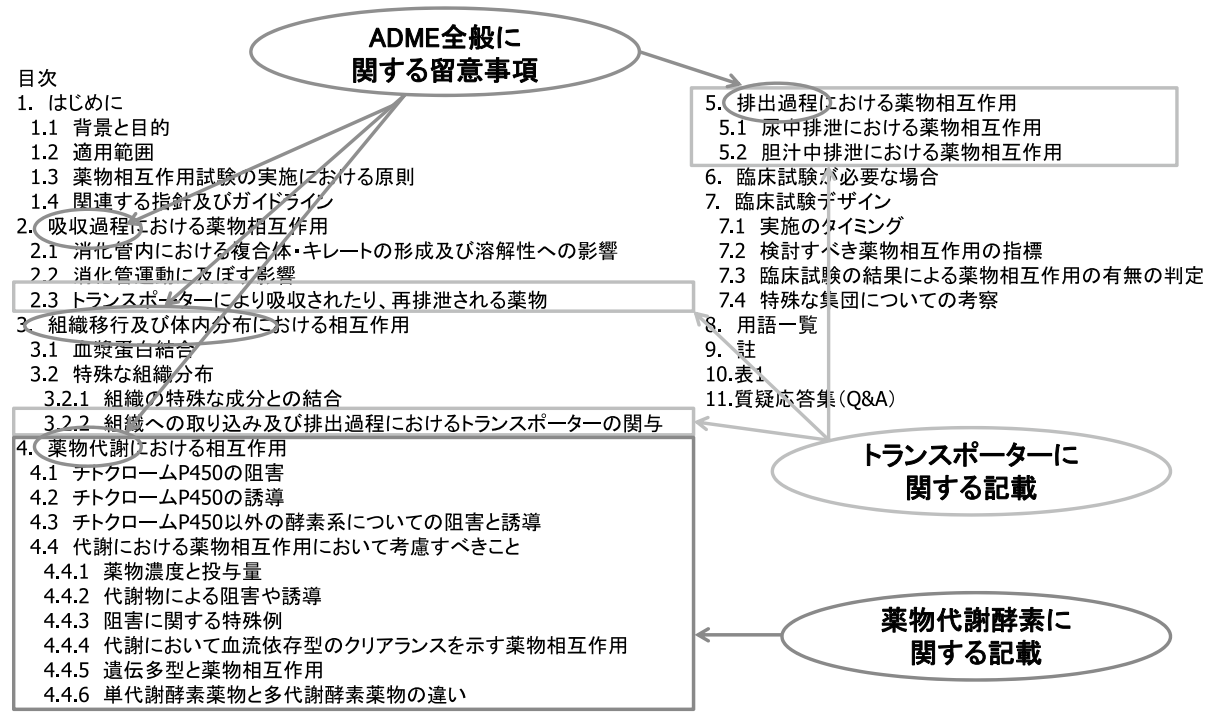

Fig. 1 「薬物相互作用の検討方法」(平成 13 年 6 月 4 日，医薬審発第 813 号)

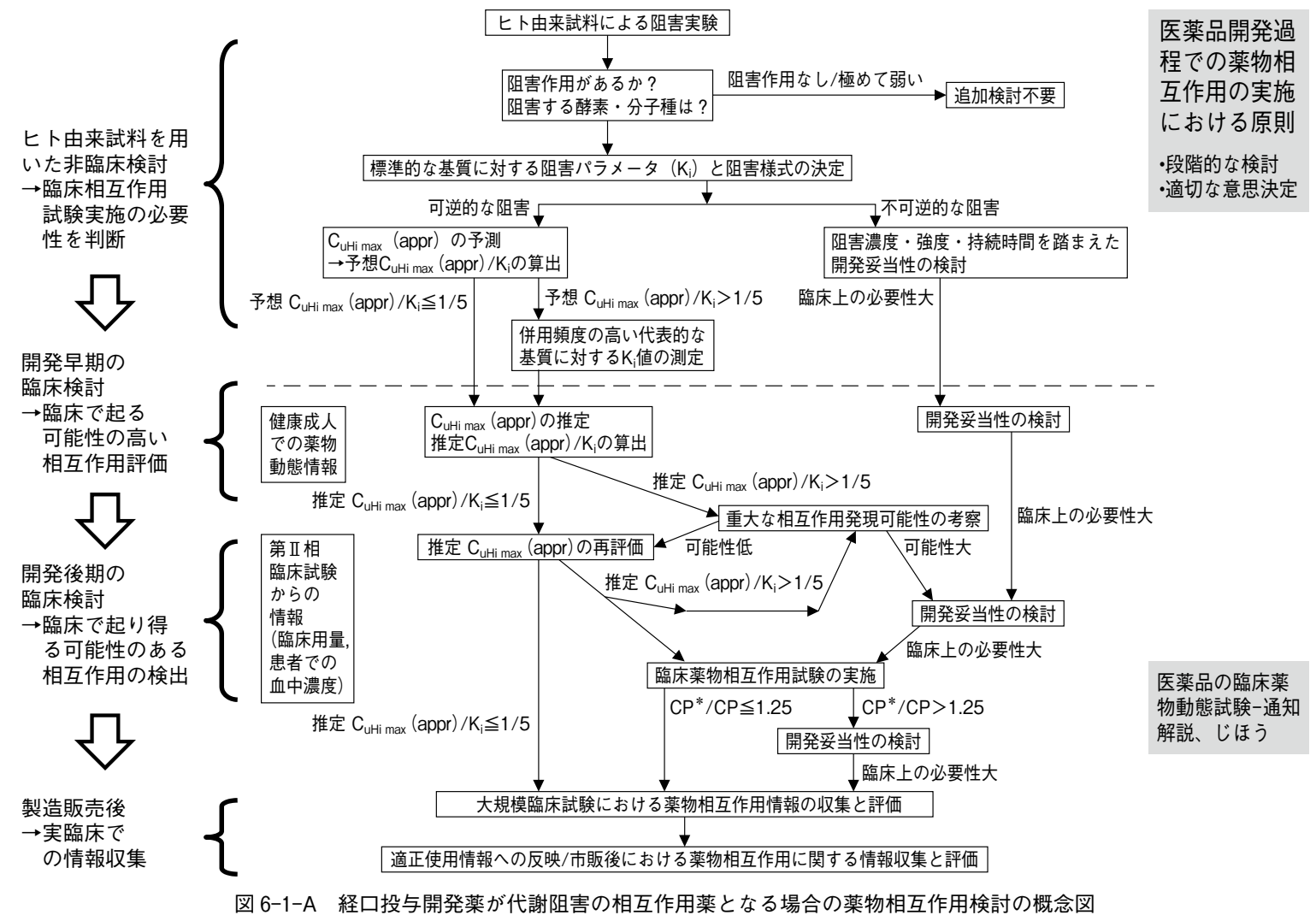

Fig. 2 医薬品開発過程での薬物相互作用の実施における原則（医薬品の臨床薬物動態試験-通知解説 ${ }^{2}$ より引用改変）

を把握する。これらの情報を承認時に添付文書等に反 映するとともに必要に応じて製造販売後の実臨床で継 続して情報収集を行う。このような検討は，個々の開 発医薬品の特性を踏まえてケースバイケースで適切な 方法を計画し, 臨床試験での検討については, 被験者 の負担やリソース等を考慮して, 安全かつ倫理的・効
率的に試験を実施することが重要である。「薬物相互 作用の検討方法」の発出以降，本指針を参考として医 薬品開発および承認審査での薬物相互作用の評価が行 われている.

「薬物相互作用の検討方法」では, 薬物相互作用をそ の発現機序により, 薬物動態学的相互作用（pharma- 
cokinetic drug interaction) と薬力学的相互 作用 (pharmacodynamic drug interaction) に分類している. 薬物動態学的相互作用は, 薬物の吸収, 分布, 代謝および排泄の過程に おける相互作用の結果, 薬物あるいは活性代 謝物の血中濃度あるいは組織分布が変化する ことにより引き起こされる. 薬力学的相互作 用は，薬理作用が重なりあったり，また打ち 消しあったりすることにより，あるいは併用 薬が薬物感受性変化を引き起こすことにより 起こる. 薬力学的相互作用の検討方法は, 薬 物の固有の薬理作用や予想される臨床適応に 応じて, 適宜判断することが必要であり, 一 般的な手法を行政指針とすることは難しい。 国内外の薬物相互作用に関する行政指針 ${ }^{1,3,4)}$ では，おもに薬物動態学的相互作用の検討方 法と留意点を示している。また，実臨床では 薬物代謝酵素, とくにシトクロム P450を介 して発現する相互作用の報告が多いこと，実験方法や 判断基準の標準化も進んでいるといった背景から，国 内外指針ともにCYP の阻害や誘導に関連した記載が 中心となっている．さらに「薬物相互作用の検討方法」 では，吸収，分布および排泄過程における相互作用の 機序として，トランスポーターについても言及してい る (Fig. 1).

\section{3 . 添付文書における相互作用に関する記載について}

薬事法第 52 条では「医薬品は, これに添附する文書 又はその容器もしくは被包に，次の各号に掲げる事項 が記載されていなければならない」として，用法，用 量その他使用および取扱い上の必要な注意を文書にて 記載することを定めており, 医療用医薬品添付文書は, 医薬品の適正使用のための基本的な要約情報である.

「薬物相互作用の検討方法」の解説書 ${ }^{2}$ では, 添付文 書への相互作用情報の反映について基本となる考え方 を以下のように提示している.

(1) 薬物相互作用による Cmax や AUC 等の薬物動態 パラメータの変動の程度とそれにより引き起こさ れる副作用の性質や程度により併用禁忌と併用注 意の別を判断すること

(2) 血中濃度上昇の程度にかかわらず, 臨床的に問題と なる重大な有害作用が生じる可能性が高い場合に は原則として併用禁忌とすること

(3) 薬物動態パラメータの変動を生じるものの, 臨床薬 物相互作用試験の結果から併用時の安全性が担保
添付文書【相互作用の項】

平成12年事務連絡: 記載例·注意事項
<相互作用の項の冒頭記載例〉 本剂は、主として肝代謝酵素CYP OO及びー部CYP $\Delta \Delta$ で代謝され る。またCYPOOの阻害作用 をもつ。

【併用禁忌】(併用しないこと)

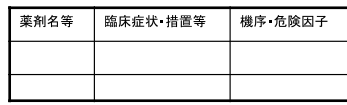

【併用注意】(併用に注意すること)

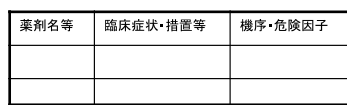

新の科学的知見に基づいた以下の記載 代謝酵素分子種と寄与割合の目安 •機序 (阻害、誘導)

代謝酵素以外 (薬物トランスポーター等)

関連データは「薬物動態」の項

(平成12年12月25日 安全対策課 事務連絡)

Fig. 3 添付文書に扔ける相互作用の項の記載事項（平成 12 年 12 月 25 日, 安全対策課 事務連絡)

できる場合は併用注意とし，相互作用を回避するた めの注意事項や投与指針について, 実施した試験の 結果等に基づいた具体的な記載が望ましいこと 添付文書に記載すべき具体的な事項と記載要領に関 しては，厚生労働省より各種通知が発出され，医薬品 の適用を受ける患者の有効性および安全性を確保する ための方策がとられている．添付文書は，昭和 58 年 5 月 18 日薬発第 385 号により作成されてきたが, 薬理 作用の強い医薬品, 高齢化社会の進展に伴う多科受診 の増加等により，副作用，使用禁忌および相互作用な どについて一層の注意が必要であるとの判断から，平 成 9 年 4 月 25 日に新記載要領の通知が発出された.

現在，相互作用に関する注意喚起と情報提供の内容 は，平成 9 年の課長通知および関連する一連の通知な らびに平成 12 年の事務連絡に基づいて作成されてい $る^{5}$ ． 相互作用は，併用禁忌（併用しないこと）と併用 注意（併用に注意すること）の措置分類に大別され， 相互作用欄において表形式を基本として注意喚起を行 う。表の記載様式は，最初に薬剤名または薬効群名を あげ，相互作用の内容と注意事項をそれぞれ臨床症 状・措置方法および機序・危険因子として記載する (Fig. 3)。また，実施した相互作用試験の成績は，併用 される可能性の高い医薬品等から優先的に薬物動態欄 に記載し，相互作用の程度が定量的に判断できるよう に症状や血中濃度の増減等の情報を数量的に記載す る.さらに，薬物代謝酵素等の知見の集積を踏まえ， 平成 12 年の事務連絡により記載の充実が図られ，相 
互作用の項の冒頭および表中において代謝酵素分子種 と寄与割合の目安, 代謝阻害や誘導あるいは代謝酵素 以外の薬物トランスポーター等の相互作用の発現機序 を記載し, 関連データを記載した薬物動態の項を参照 する旨の対応が追加された（Fig. 3).

新医薬品の承認申請時には, 承認申請資料の一部と して, 添付文書が CTD 第 1 部 1.8 項, 根拠となる非 臨床および臨床相互作用試験の報告書はそれぞれ CTD 第 4 部非臨床試験報告書および同 5 部臨床試験 報告書, 概要はそれぞれ CTD 第 2 部非臨床概要の 2.6.4 項および同臨床概要の 2.7.2 2 2.7.6 項として 編集される $(\text { Fig. 4 })^{6}$. 薬事承認後は, 医薬品医療機 器総合機構の情報提供ホームページにおいて, これら 添付文書，承認審査における検討内容（審査報告書） および CTD 概要書が閲覧可能である ${ }^{7)}$. また添付文 書の情報の最新化については, 承認取得者の責務とさ れている.

医療現場においては，製薬会社が作成する使用上の 注意解説, インタビューフォームや患者向け医薬品ガ イド等，また各医療機関が作成する院内向けの医薬品 情報集等, さまざまな情報提供資材が作成され医薬品 の適正使用推進のために用いられている。これら各種 資材の基本的な情報源は添付文書であり，医療におけ る位置付けや情報提供内容の意義は大きい.

\section{4. 薬物相互作用の検討方法と情報提供に関連した 行政指針の改訂について}

平成 9 年の添付文書記載要領改訂や平成 13 年の「薬 物相互作用の検討方法」発出から 10 数年が経過した. 薬物相互作用に関連した学問や科学技術の進歩等を踏 まえ, アカデミアや医療現場から，相互作用に関連し た検討内容の最新化の必要性や添付文書における記載 内容の充実および注意喚起の様式についての提案や問 題点が指摘されている. たとえば，同一の薬物動態上 の機序により生じる薬物相互作用の強度や寄与の程度 の違いが考慮されていない, 相互作用の影響に関する 定量的な情報が不明あるいは記載がさまざまである, 生じ得る薬物相互作用の臨床的な重要度や併用による リスクと注意喚起に関する記載の関係が不明瞭である 等, 薬剤間での記載内容や様式の不統一の指摘, およ び既承認医薬品では最新の情報が反映されていない添 付文書が多いとの指摘等である.

近年，欧米規制当局では薬物相互作用の行政指針改 訂に係る作業が進められ，昨年 2 月に米国 FDAのド ラフトガイダンスが発表され，欧州では本年 1 月より

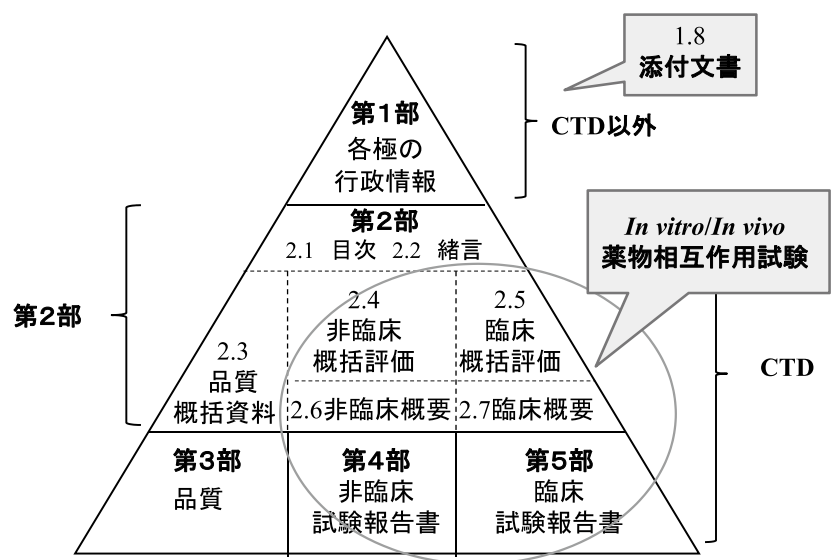

Fig. 4 新医薬品の承認申請時に提出される資料（国際 共通化資料：CTD）

$\lceil$ Guideline on the Investigation of Drug Interactions $」$ に基づく医薬品評価が行われている ${ }^{3,4)}$. 本邦では, 平 成 24 年および 25 年度の厚生労働科学研究事業におい て「薬物相互作用の検討方法」の改訂作業が進められ ている．主要な検討事項の「代謝」，「トランスポー ター」抽「「モデリング・ラベリング」について,

各々ワーキンググループを組織し，製薬会社等の基礎 および臨床開発に携わる研究者, アカデミアからは薬 物動態学会を中心に臨床薬理学会や薬剂学会の研究 者, さらに承認審査・治験相談や製造販売後の安全性 評価を行う行政担当者から成るメンバーにより検討が 行われている.

現行の「薬物相互作用の検討方法」からの主な改訂 事項として議論されている内容は以下のとおりであ る.

(1) 主要な薬物代謝酵素, 一部の薬物トランスポーター の関与を検討する際, 最新の知見を踏まえた方法論 とともに意思決定にかかわる判断基準を明記した 相互作用検討の決定樹（Decision Tree）を作成する こと

(2) 臨床相互作用の試験計画や実施にあたっての留意 事項等, とくに臨床での検討内容に関連した事項を 充実させること

(3) 生物薬品 (バイオテクノロジー応用医薬品, 生物起 源由来医薬品）との相互作用について事例を踏まえ た留意事項を記載すること

(4) 指針の根拠とする文献情報の充実を図る等, 現行の 指針の総論的な内容と比較してょり具体的, 実践的 な指針とすること

(5) 最新の欧米指針との整合化を図ること

(6) 添付文書における注意喚起と情報提供に関する基 
FDA Draft Guidance, Feb.2012 で示されたフォレストプロットの記載要領 Figure 8. The Effect of Tarious CTP Inhibitors on a Hipothetical Drug's PK as Displayed
as $90 \%$ Confidence Intertal of Geometric Nean AIC and Can Ratios.

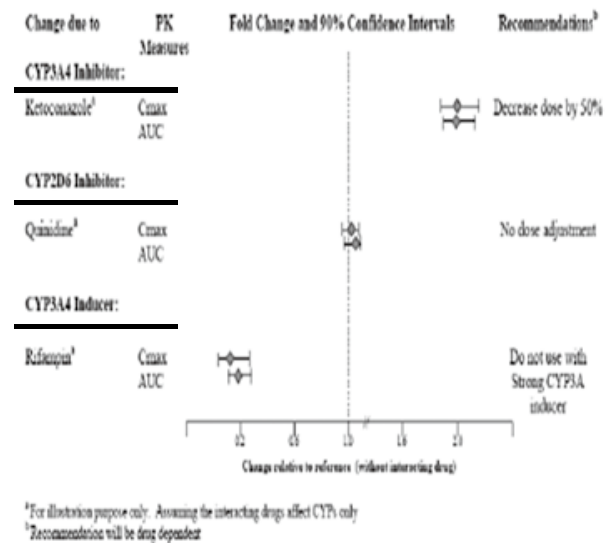

Fig. 5 薬物相互作用試験の情報提供

本原則を示すこと

相互作用の検討方法と結果の評価に加えて，注意喚 起と情報提供に関する基本的な考え方についても指針 中に明記し, 添付文書の記載要領の通知と従来以上に 関連付けて活用できるようにしたいとの方針のもと，

(6)の内容については医療用医薬品の使用上の注意の 在り方に関する研究班と意見交換を行いながら，以下 の方針にて検討を進めている.

(1) 措置分類は従来どおりの 2 分類にて相互作用欄に 記載する. 加えて, 重複記載を避けることが原則と しつつ, 生じ得る相互作用の臨床的な重要度等に基 づき，更なる注意が必要な場合にはリスクマネジメ ントのための注意事項や投与指針を相互作用欄以 外の使用上の注意の項目へも具体的に記載

(2) 臨床相互作用試験で用いる指標薬の選択や添付文 書での情報提供への活用に資するため臨床相互作 用デー夕に基づき，CYP の各分子種の阻害薬，誘 導薬および基質を強度分類により整理

(3) 臨床相互作用試験の成績, 症例報告またはモデリン グによる相互作用予測等, エビデンスレベルの異な る情報の提供方針を整理

(4) 開発段階等で実施した臨床相互作用試験はその結 果にかかわらず「薬物動態」で臨床的な影響の有無 や試験データについて必要な情報提供を行うことと し，使用者側が理解しやすい情報提供の形式の提案 国際調和・協力体制による外国臨床試験デー夕の相 互利用や薬物相互作用に関連した学問や科学技術の進
歩を背景として，最近では，本邦承認申請資料として 数多くの薬物相互作用試験が添付される医薬品が多 い. 開発段階で収集される膨大な情報の評価に基づ き，医療現場での相互作用のマネジメントに資するよ う情報提供するための形式についても考慮する必要が ある．薬物動態欄では，記述または表形式による相互 作用データの記載が一般的であったが，フォレストプ ロット等のより視覚的な方法も提案されている（Fig. $5)^{3,8,9)}$ 。また，開発段階では，起こり得るすべての相 互作用の組み合わせについて相互作用試験を実施して デー夕を収集することは不可能である．モデリングや シミュレーション等の手法の活用も考慮すべきであろ う. 医療現場において, 臨床相互作用試験の成績, 症 例報告またはモデリングによる相互作用予測等，エビ デンスレベルの異なる情報を適切に活用してもらうた めに情報を活用する側の立場に立った情報提供の形式 についても検討が必要である.

\section{5 . 添付文書の位置付けの見直しについて}

厚生科学審議会医薬品等制度改正検討部会 (平成 24 年 1 月 24 日）において，薬事法など制度改正について 議論された ${ }^{10)}$ 。添付文書は，医薬品を適正に使用する ための情報を医療現場に伝達する手段として最も基本 的なものであることから，常に最新の知見に基づいて 作成されるべきものであることという点のほかに，添 付文書の内容に対する国の責任をより明確にするとい う観点から，添付文書の位置付けについても議論され 


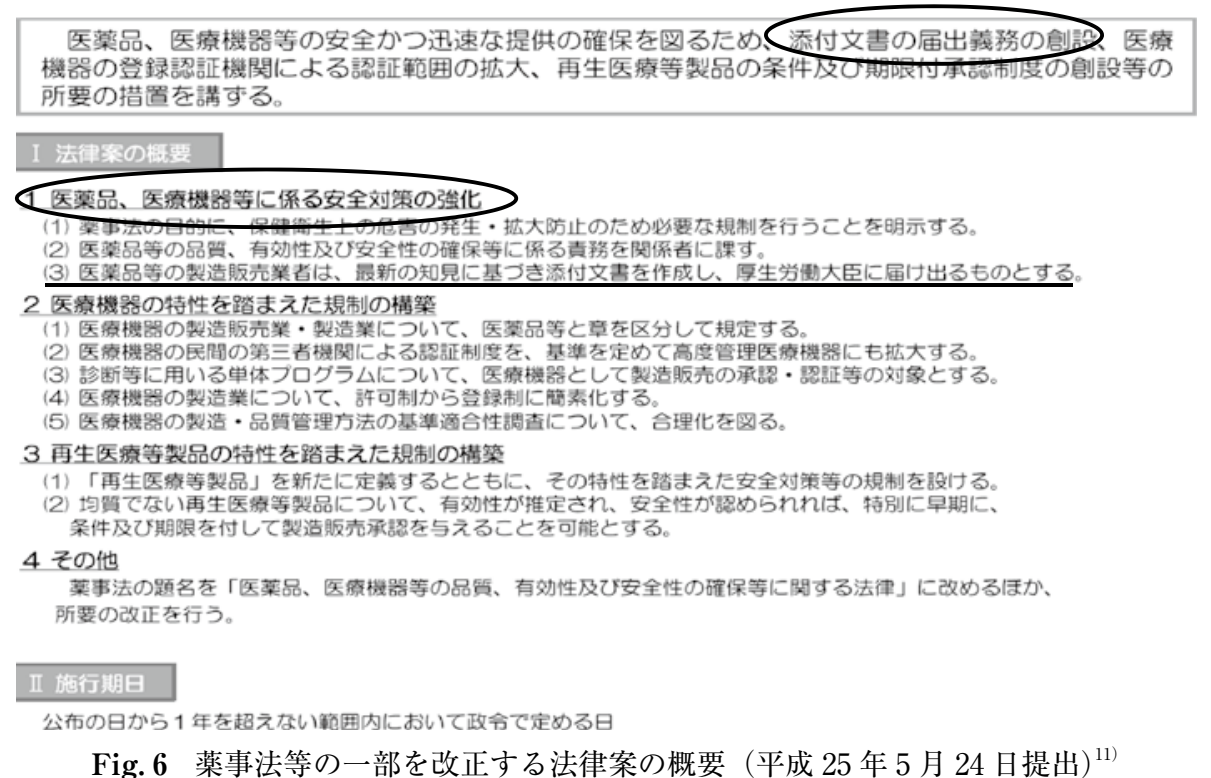

た. また，近年の情報処理技術の進展を背景として， 電子化への対応, 添付文書の記載内容の充実, 処方時 の参考情報となる有益な情報提供のあり方についても 検討すべきであると提言された。

添付文書の位置付けの見直しは，今回の薬事法改正 案のひとつの柱である。本年 5 月に国会に提出された 薬事法等の一部を改正する法律案の概要を Fig. 6 に示 $す^{11)}$. 薬事法の名称が「医薬品, 医療機器等の品質, 有効性及び安全性の確保等に関する法律」と改められ るほか, 安全対策の強化として，医薬品等の製造販売 業者は, 最新の知見に基づき添付文書を作成し，厚生 労働大臣に届け出るものとすることを明記した規定が 新設されている.

\section{6. おわりに}

医療用医薬品の添付文書における相互作用の記載と その根拠となる医薬品開発時の検討事項, また今後の 展望として, 現在改訂作業中の薬物相互作用に関する 本邦の指針および薬事法改正案における添付文書に関 する内容について紹介した。

医療現場での薬物治療を適切にマネジメントするた めには，併用による薬物動態の変化やその臨床的な意 義について，データに基づいて評価し適正な情報提供 を行う必要がある. 改訂ガイドラインに基づく開発時 の薬物相互作用の検討内容が適正に情報提供され, 医 療現場での相互作用のリスク管理に資することを期待 したい.
本稿は著者の個人的見解であり, 医薬品医療機器総合機構 および厚生労働省としての見解ではない，また実務にあたっ ては, 最新の関連法令・通知等を参照いただきたい.

\section{文献}

1）薬物相互作用の検討方法について. 平成 13 年 6 月 4 日, 医薬審 発第 813 号.

2）臨床薬物動態試験・薬物相互作用ガイドライン検討班（編）。医 薬品の臨床薬物動態試験一通知解説. ビほう, 2003.

3) Drug Interaction Studies--Study Design, Data Analysis, Implications for Dosing, and Labeling Recommendations (Draft guidance). U.S. FDA, February 2012.

4) Guideline on the Investigation of Drug Interactions. EMA, January 2013.

5）医療用医薬品添付文書の記載要領について，医療用医薬品の使 用上の注意の記載要領について. 平成 9 年 4 月 25 日, 薬発第 606 号, 薬発第 607 号, 薬安第 59 号. 平成 12 年 12 月 25 日, 安 全対策課事務連絡.

6）新医薬品の製造又は輸入の承認申請に際し承認申請書に添付す べき資料の作成要領について. 平成 13 年 6 月 21 日，医薬審発 第 899 号, ICH CTD ガイドライン.

7）医薬品医療機器情報提供ページ. [http://www.info.pmda.go.jp]

8) Menon-Andersen D, Yu B, Madabushi R, Bhattaram V, Hao W, Uppoor RS, et al. Essential pharmacokinetic information for drug dosage decisions: a concise visual presentation in the drug label. Clin Pharmacol Ther. 2011; 90 (3) : 471-4.

9) Warnings and Precautions, Contraindications, and Boxed Warning Sections of Labeling for Human Prescription Drug and Biological Products--Content and Format. FDA, October 2011.

10）薬事法等制度改正についてのとりまとめ. 平成 24 年 1 月 24 日, 厚生科学審議会医薬品等制度改正検討部会. [http://www. mhlw.go.jp/stf/shingi/2r98520000020uxm-att/2r98520000020uz 3.pdf (accessed 2013-10-31) ]

11）薬事法等の一部を改正する法律案の概要. [http://www.mhlw. go.jp/topics/bukyoku/soumu/houritu/dl/183-52.pdf (accessed 2013-10-31) ] 